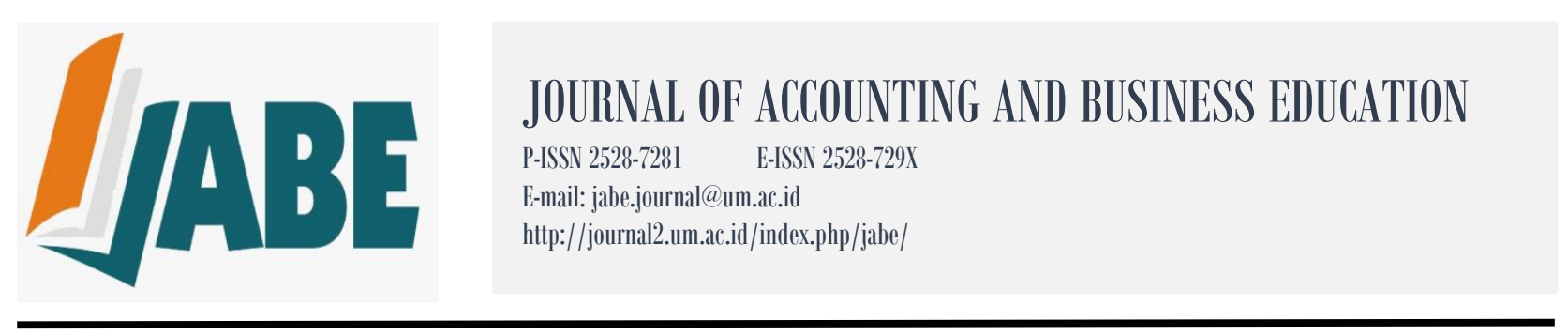

\title{
Assessing the Relevance of Undergraduate Auditing Education: A Scoping Review
}

\author{
Diana Tien Irafahmi ${ }^{1,2}$ \\ ${ }^{1}$ School of Education, Faculty of Humanities, Curtin University, Australia \\ ${ }^{2}$ Accounting Department, Faculty of Economics, Universitas Negeri Malang, Indonesia \\ email: diana.tien.fe@um.ac.id
}

DOI: http://dx.doi.org/10.26675/jabe.v4i1.9114

\begin{abstract}
While previous literature review studies have explored the current status of accounting education, a literature review that focuses explicitly on auditing education is scarce. The objective of this scoping review was to map the existing studies that assess the relevance of undergraduate auditing education to meet contemporary auditing practices. The scoping review followed the protocol outlined by Arksey and O'Malley (2005) that has five main stages: (1) identifying research questions; (2) identifying relevant studies; (3) study selection; (4) data charting, and (5) collating, summarizing and reporting the results. The reviewed studies were selected from three electronic databases: ProQuest, Taylor \& Francis, and Science Direct within 25 years time span (1995-2019). The results of the scoping review indicated that the majority of the studies recognize a positive shift both in terms of content and pedagogy to keep its relevance to professional demand. However, as has been claimed by Johnson, Baird, Caster, and Dilla (2003), the shift in auditing education is occurring more slowly than the demand of profession. Emphasis should be given to content as a gap still exists between auditing educators and practitioners.
\end{abstract}

Keywords: Auditing education, accounting education, undergraduate, scoping review, higher education

\section{INTRODUCTION}

Auditing practices are changing rapidly in line with changes in the business world. The main factors that contribute to the transformation of the business world are the proliferation of accounting and auditing regulations and the extensive use of technology (Bryan \& Smith, 1997; Reinstein, Churyk, \& Tate, 2018).

Arens and Elder (2006) explained that new regulations in the audit field emerged following the discovery of fraud audits. Although the phenomenal scandals were the Enron or WorldCom in the early 2000s, in fact major frauds had been discovered long before (Arens \& Elder, 2006). Since the late 1930s, McKesson Robbins scandal has been responded to by regulators and standard setters by issuing Statements on Auditing Procedures, which detailed requirements for confirming receivables and observing inventory (Arens \& Elder, 2006). In the 1970s, after Equity Funding and Continental Vending fraud, rules regarding peer review and division of firms emerged (Arens \& Elder, 2006). Subsequently, in the 1980s, a regulation was issued regarding the obligation to document the understanding of controls and conduct analytical procedures, after the case of Crazy Eddie and ESM Government Securities (Arens \& Elder, 2006). The Sarbanes-Oxley Act (SOX) is a regulation in 2002 that has significant impact on the auditing profession and practices (Arens \& Elder, 2006). The issuance of new regulations in the field of 
auditing is an indication of the responsiveness of regulators and standard setters to overcome financial fraud. Unfortunately, the efforts of regulators and setter standards in making regulations are more curative than preventive, given that new rules that significantly change auditing practices are always published after a scandal.

In addition to regulation, the transformation of the business world and auditing practices are also triggered by technology. Information Technology (IT) is believed to have a positive impact on audit quality. IT is a substantial tool for increasing audit effectiveness and efficiency (Antcliff, Doren, Harris, \& Hayes, 2012; Bierstaker, Burnaby, \& Thibodeau, 2001; Borkowski, Bukics, \& Welsh, 2007). Bierstaker et al. (2001) explained that there are at least three substantial stages in auditing that use IT intensively: audit planning, audit testing and audit documentation. In the audit planning stage, IT helps auditors to assess the internal and external risks of the client's business that will affect the audit process (Bierstaker et al., 2001). IT also plays a substantial role in the audit testing phase because it saves time to complete audit procedures such as extracting data, selecting samples, performing calculations that were previously done manually (Bierstaker et al., 2001). While in the audit documentation phase, IT has changed the form of audit documentation, from the paper documentation to electronic documentation that makes it easier for auditors to share and trace audit documentation between auditors (Bierstaker et al., 2001). In line with the opinion of Bierstaker et al. (2001), Herron and Morozzo (2008) explained that a major change in audit practices is the use of technology to replace manual processes. All audit work, such as making program audits, selecting samples, designing schedules with clients, doing substantive analytical procedures, and client research always involves the use of IT (Herron \& Morozzo, 2008).

The transformation in the business world and audit practices as described above has resulted in the strong demands for an adaptive auditing education (Arens \& Elder, 2006). The International Accounting Education Standards Board (2017) states that undergraduate accounting program in universities is the first institution to educate prospective accountants/professional auditors. IAESB (International Accounting Education Standard Board), AICPA (American Institute of Certified Public Accountants), and The Pathways Commission have designed minimum criteria for graduates of accounting programs that can be used as a reference for universities in designing accounting education programs, including auditing sub-disciplines (American Institute of Certified Public Accountants, 2018; International Accounting Education Standards Board, 2017; The Pathways Commission, 2012, 2015). Thus, auditing education should be able to develop the competences of prospective auditors so that they are in line with the expectations of stakeholders. Unfortunately, audit education is never free from criticism (Armitage, 2008; Armitage \& Poyzer, 2010; Blouch, Ulrich, \& Michenzi, 2015, 2016; Bryan \& Smith, 1997; Johnson et al., 2003; Ulrich \& Blouch, 2018; Ulrich, Michenzi, \& Blouch, 2009).

Indications of auditing education mismatch with stakeholder expectations can been seen in the results of Frakes (1987). More than three decades ago, Frakes (1987) surveyed in the US to gather information related to problems faced by auditing education at the undergraduate level. With 470 university respondents in the US, this survey shows that "auditing is seen as a difficult course to teach" (Frakes, 1987, p. 124). Auditing educators who are respondents of this study find it difficult to harmonize auditing teaching with current audit practices. The main problem, which then was synthesized, is in the area of curriculum design, development of relevant teaching materials, dissemination of technology and ongoing audit education for auditing educators.

This study aimed to map the existing literature related to the relevance of auditing education to meet the current auditing practices. The previous scoping studies that focus on the area of auditing education are unknown. In the broader area, such as accounting education, the literature review has been conducted serially by Apostolou et al. (see eg Apostolou, Dorminey, Hassell, \& Hickey, 2019; Apostolou, Dorminey, Hassell, \& Rebele, 2015, 2016, 2017, 2018; Apostolou, Dorminey, Hassell, \& Watson, 2013; Apostolou, Hassell, Rebele, \& Watson, 2010). Literature review research by Apostolou et al. aimed to summarize and review articles published in several leading accounting education journals such as the Journal of Accounting Education, Accounting Education, Issues in Accounting Education, and Advances in Accounting Education: Teaching and Curriculum Innovations, and The Accounting Educators' Journal. Research by Apostolou et al. covered a variety of sub-disciplines in accounting education, such as tax, 
auditing, information system, managerial accounting, and financial accounting. Apostolou et al. applied the traditional literature review method, which according to Munn et al. (2018) tends to be subjective because it is very dependent on the pre-existing knowledge and experience of the researcher. In contrast to the literature review of Apostolou et al., this study applied the scoping review method and limits the area in the field of auditing education.

Scoping review is popularly used primarily in the field of health science research (O'Brien et al., 2016). The framework to conduct scoping review can be seen in Arksey and O'Malley's paper (2005). Munn et al. (2018) detail the differences in the characteristics of scoping review and systematic review, especially in terms of its objectives. Scoping review is used if the purpose of the review is to "identify knowledge gaps, scope a body of literature, clarify concepts, investigate research conduct, or to inform a systematic review" (Munn et al., 2018, p. 6). Another distinguishing feature between scoping and systematic review is the synthesis of findings. Systematic reviews are more rigorous than scoping reviews in terms of synthesizing findings, using statistical meta-analysis or meta-synthesis or a combination of the two if a mixed-method review is applied (Munn et al., 2018). The respondents in the study conducted by O'Brien et al. (2016) explain the reasons for their preferences of applying scoping review because scoping review is considered a powerful tool for mapping a topic with an approach that is not "as rigid as systematic reviews" (O’Brien et al., 2016, p. 4).

\section{METHODS}

The scoping review method adopted in this study was from Arksey and O'Malley (2005). Arksey and O'Malley (2005) used the 5-step scoping review approach, including (1) identifying the research questions; (2) identifying relevant studies; (3) study selection; (4) charting the data, and (5) collating, summarizing and reporting the results (p. 22).

O'Flaherty and Phillips (2015) applied the 5-step approach to scoping a review of flipped classrooms. Johnston, Crooks, Snyder, and Kingsbury (2010) also followed the protocol from Arksey and O'Malley to understand the impact of Medical Tourism on destination and departure countries. Although the scoping study by Johnston et al. (2010) and O'Flaherty and Phillips (2015) are outside the auditing education area, the description of the steps in scoping a review in their research has provided practical guidance for scoping a review in this study.

\section{Identifying the Research Questions}

It is substantial to identify research questions in the initial stages of the scoping review. By establishing research questions, researchers can design strategies for conducting literature searches while ensuring that substantive areas are covered (Arksey \& O'Malley, 2005; O'Flaherty \& Phillips, 2015). The research question in this study is: "What is known from the existing literature about the relevance of undergraduate auditing education to meet contemporary auditing practice?"

\section{Identifying Relevant Studies}

In an effort to identify literature relevant to research questions, key search terms were made. Key search terms that are closely related to auditing education at the undergraduate level are: "auditing education" OR "auditing curriculum"; "auditing education" AND "undergraduate"; "auditing curriculum" AND "undergraduate". Boolean operators were used to narrow down the searching area and combine the required terms.

Arksey and O'Malley (2005) explain that searching could go through different sources, such as "electronic databases, reference lists, hand-searching of key journals, existing networks, relevant organizations and conferences" (p. 22). In this study, the source used was electronic database with the consideration that the database encapsulates many reputable journals so that searching for literature through an electronic database is more effective and efficient. The electronic databases selected were: 
ProQuest, Science Direct, and Taylor \& Francis. These three databases are prevalent for searching literature in the area of business or business education.

The criteria used in the process of searching literature are depicted in Table 1 . The period used was 25 years, from 1995 to 2019 . The 25 -year time span was considered sufficient to track the relevance of auditing education research. The publication type chosen was empirical article peer-reviewed journals that had been published in the English language. The geographic region was not limited to certain countries. All empirical studies from various countries were included in the criteria as long as they met the other criteria mentioned earlier.

Table 1. Inclusion criteria

\begin{tabular}{lll}
\hline Criterion & Inclusion & \\
\hline $\begin{array}{l}\text { Period } \\
\text { Language }\end{array}$ & English & $\begin{array}{l}\text { 25 years of observation } \\
\text { Most peer-reviewed articles are published in } \\
\text { English }\end{array}$ \\
Publication type & Journal article & $\begin{array}{l}\text { Only empirical peer-reviewed articles are included } \\
\text { in the study }\end{array}$ \\
Geographic region & All & Findings from all countries \\
\hline
\end{tabular}

\section{Study Selection}

The results of searching three electronic databases using key search terms found 268 articles, 46 articles were from Taylor and Francis, 81 articles were from Science Direct, and the rest were 141 articles from ProQuest. These articles were then examined to determine their suitability with the research question. The articles were also checked to find the possibility of duplicate articles within different databases.

At this stage of the study selection, 256 articles were discarded. Most articles that did not fit the research question were because: (1) they did not discuss auditing education at the undergraduate level (for example, at the master level or CPE-Continued Professional Education); (2) The articles were not empirical research; and (3) They did not address the issue of auditing education relevancy.

\section{Charting the Data}

At the data charting stage, selected articles were extracted to summarize the most substantial data. The data recorded were data about the author, year of study, location of study, objectives, design/method, and findings.

\section{Collating, Summarizing and Reporting the Results}

The last stage of scoping review was collating, summarizing, and reporting research results. Collating produced a table in which contains the extraction of articles carried out at the stage of charting the data. Summarizing produced main themes or patterns from the main findings, and reporting produced report format, which in this case was for publication purpose. Table 2 shows the results of collating data.

Table 2. Data Collating

\begin{tabular}{|c|c|c|c|c|c|c|}
\hline No & Author & Year & $\begin{array}{l}\text { Study } \\
\text { location }\end{array}$ & Aims & Design/method & Major Findings \\
\hline 1 & $\begin{array}{l}\text { (Bryan \& } \\
\text { Smith) }\end{array}$ & 1997 & US & $\begin{array}{l}\text { Understanding the } \\
\text { auditing } \\
\text { educators' } \\
\text { perception on the } \\
\text { importance of the } \\
\text { topics taught in } \\
\text { the Auditing } \\
\text { course }\end{array}$ & $\begin{array}{l}\text { A survey on } 223 \\
\text { auditing } \\
\text { educators }\end{array}$ & $\begin{array}{l}\text { There was a common perception } \\
\text { among Auditing educators } \\
\text { regarding the most substantial } \\
\text { topics that must be taught in the } \\
\text { Auditing course }\end{array}$ \\
\hline
\end{tabular}




$\begin{array}{llll}\text { (McCartne } 2002 \text { US } & \begin{array}{l}\text { Investigating the } \\ \text { gap between }\end{array} & \begin{array}{l}\text { A survey on } 40 \\ \text { Internal }\end{array} \\ \text { y, Marden, } & & \begin{array}{l}\text { Internal Auditing } \\ \text { topics taught and }\end{array} & \text { Auditing } \\ \text { \& Adair) } & \text { educators and } \\ & & \text { those needed by } & 130 \text { Internal } \\ & & \text { practitioners } & \text { Auditors }\end{array}$

In general, there was a similar perception between educators and practitioners regarding substantial topics to teach, but there were several topics that differ in their level of preference (for example topics related to technology in Auditing)

\begin{tabular}{|c|c|c|c|c|c|c|}
\hline 3 & $\begin{array}{l}\text { (Johnson et } \\
\text { al.) }\end{array}$ & 2003 & $\begin{array}{l}\text { Auditing } \\
\text { syllabi } \\
\text { from the } \\
\text { US and } \\
\text { Canada }\end{array}$ & $\begin{array}{l}\text { Understanding the } \\
\text { suitability of the } \\
\text { syllabi to the } \\
\text { professional } \\
\text { requirements }\end{array}$ & $\begin{array}{l}\text { Content analysis } \\
\text { of } 262 \text { Auditing } \\
\text { syllabi }\end{array}$ & $\begin{array}{l}\text { There was an increase in the } \\
\text { pedagogical and technological } \\
\text { resources aspects of learning, but } \\
\text { the increase were too slow } \\
\text { compared with the profession } \\
\text { demands }\end{array}$ \\
\hline 4 & $\begin{array}{l}\text { (Greenstei } \\
\text { n \& } \\
\text { McKee) }\end{array}$ & 2004 & US & $\begin{array}{l}\text { Understanding the } \\
\text { perception of } \\
\text { Auditing } \\
\text { educators and } \\
\text { practitioners } \\
\text { regarding IT } \\
\text { Auditing }\end{array}$ & $\begin{array}{l}\text { A survey on } 304 \\
\text { educators and } \\
246 \\
\text { practitioners }\end{array}$ & $\begin{array}{l}\text { There was a learning gap between } \\
\text { academics and practitioners } \\
\text { regarding IT Auditing. The } \\
\text { academics consider IT Auditing can } \\
\text { be learned in the workplace while } \\
\text { the practitioners encourage IT } \\
\text { Auditing to be learned while } \\
\text { studying }\end{array}$ \\
\hline 5 & (Armitage) & 2008 & $\begin{array}{l}\text { Accounti } \\
\text { ng } \\
\text { faculty } \\
\text { directory } \\
\text { (mostly } \\
\text { the US } \\
\text { and } \\
\text { Canada) }\end{array}$ & $\begin{array}{l}\text { Identifying } \\
\text { auditing topic } \\
\text { ranking change } \\
\text { from the year } \\
2000 \text { to } 2005\end{array}$ & $\begin{array}{l}\text { A survey on } 217 \\
\text { auditing } \\
\text { educators in } \\
2000 \text { and } \\
311 \text { Auditing } \\
\text { educators in } \\
2005\end{array}$ & $\begin{array}{l}\text { There was a change of auditing } \\
\text { educators on the importance of } \\
\text { auditing topic to teach from } 2000 \text { to } \\
2005\end{array}$ \\
\hline 6 & $\begin{array}{l}\text { (Ulrich et } \\
\text { al.) }\end{array}$ & 2009 & US & $\begin{array}{l}\text { Finding out the } \\
\text { importance of } \\
\text { auditing topic } \\
\text { rating and } \\
\text { whether the } \\
\text { Auditing } \\
\text { textbooks have } \\
\text { been effective in } \\
\text { developing the } \\
\text { topic }\end{array}$ & $\begin{array}{l}\text { A survey on } 71 \\
\text { Auditing } \\
\text { educators }\end{array}$ & $\begin{array}{l}\text { There were four quadrants to } \\
\text { connect the results of the level of } \\
\text { importance to the level of } \\
\text { effectiveness. Educators should } \\
\text { prioritize the teaching of topics in } \\
\text { quadrants one and two. Textbook } \\
\text { authors and publishers should focus } \\
\text { on topics in quadrant two since the } \\
\text { textbooks were not to be effective } \\
\text { in their coverage to develop topics } \\
\text { in quadrant } 2\end{array}$ \\
\hline 7 & $\begin{array}{l}\text { (Armitage } \\
\text { \& Poyzer) }\end{array}$ & 2010 & US & $\begin{array}{l}\text { Comparing the } \\
\text { educators' and the } \\
\text { auditing } \\
\text { practitioners' } \\
\text { perception } \\
\text { regarding the } \\
\text { importance of } \\
\text { Auditing topic }\end{array}$ & $\begin{array}{l}\text { A survey on } 179 \\
\text { academics and } \\
139 \\
\text { practitioners }\end{array}$ & $\begin{array}{l}\text { There was a difference between the } \\
\text { academics' perception and those of } \\
\text { the practitioners'. The practitioners } \\
\text { argued that the substantial topics } \\
\text { are the ones related to the practice, } \\
\text { while academics tend to prioritize } \\
\text { topics related to the theory. }\end{array}$ \\
\hline 8 & $\begin{array}{l}\text { (Chaffey, } \\
\text { Van } \\
\text { Peursem, } \\
\text { \& Low) }\end{array}$ & 2011 & $\begin{array}{l}\text { New } \\
\text { Zealand }\end{array}$ & $\begin{array}{l}\text { Understanding the } \\
\text { topics, skills, and } \\
\text { pedagogy that are } \\
\text { substantial for } \\
\text { students' career } \\
\text { development from }\end{array}$ & $\begin{array}{l}\text { A survey on } 130 \\
\text { auditors }\end{array}$ & $\begin{array}{l}\text { To the practitioners, the substantial } \\
\text { topics were those that sharpen } \\
\text { judgment, critical thinking, } \\
\text { practical skills, and ethics. } \\
\text { Substantial skills were } \\
\text { communication skills, practical }\end{array}$ \\
\hline
\end{tabular}


the practitioners' point of view. elements, and judgment-based procedures. The substantial pedagogies are case studies, visiting professional educators, and computer-based audit.

\begin{tabular}{|c|c|c|c|c|c|c|}
\hline 9 & $\begin{array}{l}\text { (Blouch et } \\
\text { al.) }\end{array}$ & 2015 & US & $\begin{array}{l}\text { Survey the CPA } \\
\text { regarding the } \\
\text { relevance of } \\
\text { auditing education }\end{array}$ & $\begin{array}{l}\text { A survey on } 91 \\
\text { public } \\
\text { accounting } \\
\text { firms }\end{array}$ & $\begin{array}{l}\text { Of } 63 \text { topics, there were } 31 \text { topics } \\
\text { whose substantiality rating was } \\
\text { above the total mean, and } 32 \text { topics } \\
\text { whose substantiality rating was } \\
\text { below the total mean. The most } \\
\text { substantial topics, according to } \\
\text { CPA, were those related to auditing } \\
\text { practices. }\end{array}$ \\
\hline 10 & $\begin{array}{l}\text { (Blouch et } \\
\text { al.) }\end{array}$ & 2016 & US & $\begin{array}{l}\text { Identifying the } \\
\text { effectiveness of } \\
\text { auditing textbooks } \\
\text { in covering pre } \\
\text { and post SOX } \\
\text { auditing topics }\end{array}$ & $\begin{array}{l}\text { A survey on } \\
\text { Pre-SOX: } 101 \\
\text { and } \\
\text { Post-SOX: } 71 \\
\text { educators }\end{array}$ & $\begin{array}{l}\text { Several auditing topics had post- } \\
\text { SOX higher effectiveness rating, } \\
\text { but there were also several topics } \\
\text { had post-SOX lower effectiveness } \\
\text { rating. Since there were many } \\
\text { substantial topics to cover in } \\
\text { auditing course, the need for } \\
\text { advanced auditing course is } \\
\text { necessary. }\end{array}$ \\
\hline 11 & $\begin{array}{l}\text { (Ulrich \& } \\
\text { Blouch) }\end{array}$ & 2018 & US & $\begin{array}{l}\text { Understanding the } \\
\text { perception of } \\
\text { CPA regarding } \\
\text { textbooks } \\
\text { suitability in } \\
\text { developing } \\
\text { substantial topics } \\
\text { to teach in } \\
\text { auditing courses. }\end{array}$ & $\begin{array}{l}\text { A survey on } 91 \\
\text { CPA firms }\end{array}$ & $\begin{array}{l}\text { For the practitioners, in general, the } \\
\text { textbooks were good enough in } \\
\text { developing substantial auditing } \\
\text { topics to teach, yet special attention } \\
\text { to topics in quadrant II is necessary }\end{array}$ \\
\hline 12 & $\begin{array}{l}\text { (Reinstein } \\
\text { et al.) }\end{array}$ & 2018 & US & $\begin{array}{l}\text { Identifying } \\
\text { learning resources } \\
\text { and learning } \\
\text { activities applied } \\
\text { in Auditing } 2 \\
\text { courses }\end{array}$ & $\begin{array}{l}\text { A survey on } \\
\text { Members of } \\
\text { AAA auditing } \\
\text { section }\end{array}$ & $\begin{array}{l}\text { The surveys showed the diversity of } \\
\text { learning resources and learning } \\
\text { activities applied in Auditing } 2 \\
\text { courses at universities in the US. }\end{array}$ \\
\hline
\end{tabular}

\section{RESULTS}

With a 25-year time span from 1995-2019, only 12 empirical studies were found to be most suitable for research questions. Nine studies (75\%) research sites were in the US, 1 study (8\%) was in the US and Canada, and 1 study (8\%) covered several countries, but most of the respondents were from the US and Canada, while 1 study originating from outside the US was from New Zealand. Most studies publication years (92\%) were above the year 2000, and only 1 study (8\%) could be identified from the year before 2000. This was an indication that the 2002 Sarbanes-Oxley Act (SOX) has triggered researchers to seek the gap between auditing education and auditing practices. All studies deployed a survey research design, except for one study used a content analysis design.

The approach taken to determine the relevance of auditing education from these studies was by surveying stakeholders of auditing education: auditing educators and/or auditing practitioners. Blouch et al. (2016), Bryan and Smith (1997), Armitage (2008), Ulrich et al. (2009), and Reinstein (2018) surveyed auditing educators. Chaffey et al. (2011), Blouch et al. (2015), Ulrich \& Blouch (2018) observed auditing practitioners. McCartney et al. (2002), Greenstein \& McKee (2004), Armitage \& Poyzer (2010) examined 
both two parties: educators and practitioners. Johnson et al. (2003) collected data from auditing educators, but the focus of their study was on the auditing syllabus.

Bryan and Smith (1997) conducted a study to determine the importance of 31 topics of auditing to be taught at the auditing course. The topics were taken from 6 leading auditing books. In general, 223 surveyed auditing educators in the US had similar opinions about which topics were relevant and substantial to teach. The ten most substantial topics were generally accepted auditing standards, riskmateriality-engagement strategy audits, internal controls, evidence audits, audit reports, auditors' professional responsibility and legal liability, inherent and control risk assessing, substantive tests, departures from unqualified opinions, and AICPA Code of Professional Conduct. Topics about technology, were perceived as less substantial to teach. The reason was probably because educators' expectation for students to learn auditing technology in other courses such as accounting information system. Besides, educators thought the topic could be learnt during an in-house training session in accounting firms. Further, the majority of educators stated that topics that must be covered were too many and were not enough to be taught in 1 semester. In addition, the topics taught did not bring real-world auditing closer to students.

McCartney, Marden, and Adair (2002) showed that there were topics of auditing whose preferences were perceived different by academics and practitioners. Topics related to technology in auditing were perceived to get higher ranking (more substantial to be taught) by auditors than by auditing educators. Both practitioners and academics considered that case studies and audit practitioners' guest lecturers in auditing classrooms are substantial to excel the status of auditing education.

Johnson et al. (2003) analyzed whether auditing syllabus has adopted professional aspects such as thinking skills, communication, and IT. The results of 262 syllabi study in the US and Canada showed positive and negative sides. On the positive side, in terms of pedagogy, there have been efforts to improve thinking skills, communication, and IT, through case studies, group activities, presentations, and writing assignments. Technology resources such as video and internet assignments are also available for teaching auditing. The negative side, according to Johnson et al., was that the auditing courses that integrate IT usage were minimal. Besides, auditing course was mostly offered in one course. Johnson et al. (2003) argued that offering one auditing course without any advanced auditing courses would impede the pace of auditing education to remain relevant to the demands of the profession.

Greenstein and McKee (2004) stated that there was a learning gap between practitioners and academics. From 304 academics and 246 practitioners surveyed, there were indications that academics tend to have a low level of IT knowledge. Academics assumed that mastery of technology in auditing can be learned when they enter the workforce. On the other hand, practitioners believed that knowledge about technology must be covered by auditing course.

Armitage (2008) identified the ranking of 41 auditing topics and changes in ranking from the year 2000 to 2005. The perception of auditing educators about the ranking of the importance of auditing topics underwent changes in the two years. Topics considered to be more substantial in 2005 than in 2000 were reports on internal control, fraud awareness, and working papers, while topics considered to be less substantial in 2005 than in 2000 were assurance services, information systems auditing, computer auditing techniques, governmental/not-for-profit auditing standards, and legal liability of auditors (Armitage, 2008, p. 935). The topics that were considered unimportant both in the 2000 and 2005 surveys was the auditing history and governmental audit/auditing for not for profit organizations. The focus of teaching auditing remains the same in both years, that was on external auditing. Another finding was that in 2005, there was a strong tendency to balance teaching theory and practice.

Ulrich et al. (2009) examined the level of importance of 63 topics of auditing and the level of effectiveness of auditing textbooks to develop important topics in auditing. The results of the study were then mapped into four quadrants. Quadrant 1 was a place to map topics that were substantial and textbooks have been effective in developing the topics. There were 28 topics in Quadrant 1. Quadrant 2 consisted of a reasonably substantial topic, but textbooks were less effective at developing the topics. Seven topics fall into this category. Most of the topics in Quadrant 2 are related to fraud and ethics. Quadrant 3 and 4 contain topics that were less substantial or less relevant to the demands of the 
profession. The 16 topics in Quadrant 3 were less covered by auditing textbooks, whereas the 12 less substantial topics in Quadrant 4 were developed in the auditing Textbook.

Armitage and Poyzer (2010) found that there were differences in the perceptions of educators and practitioners in rating the importance of auditing topics to be taught in auditing courses. The practitioners believed that the substantial topics taught are those related to auditing practices such as documentation, fraud techniques, tests of controls, and substantive testing. Instead, the educators consider a substantial topic to be related to theory for conducting audits, for example, audit risk, internal control, financial statement assertions, and fraud awareness. Regarding the topic of fraud, educators perceived that teaching fraud awareness was more important than teaching fraud techniques. On contrary, practitioners saw the need to put more emphasis on teaching fraud techniques. Similarly, the topic of IT auditing for practitioners is a very important topic to be taught, while educators consider it less substantial. The topic of audit reports for educators needs to be discussed in depth, while for practitioners the topic is sufficiently discussed briefly, by giving examples of the correct report form and its format.

Chaffey, Van Peursem, and Low (2011) in the results of a survey of 130 auditors found that auditors emphasized the importance of teaching auditing in the aspects of communication skills, practical skills, ethics, judgment and critical thinking. To get practical skills, auditing theory needs to be integrated with auditing practice through case studies, visiting professional educators, computer based audits and infield learning experience. The combination of theory and practice in auditing education is very substantial because there are many accounting graduates who understand the theory but are unable to apply the theory in practice, as expressed by the auditors in this study.

Blouch et al. (2015) conducted a CPA (Certified Public Accountant) survey related to the relevance of auditing education. For CPAs, of the 63 topics surveyed, there were 31 topics that received a rating above the total mean, indicating a high level of importance, and there were 32 topics that received a rating below the total mean which indicates lower importance levels. Topics related to auditing practice were more substantial than topics related to concepts. Examples of substantial topics according to the CPA are detailed tests of balances, analytical procedures, audit and business risks, evidence and documentation of work performed.

Blouch et al. (2016) used SOX as a cut-off to examine the relevance of the content of the auditing and effectiveness of the auditing text in developing the content. 101 educators surveyed before SOX, and 71 educators after SOX. After the issuance of SOX regulations, the direction of the auditing curriculum has changed. There were several auditing topics with a higher effectiveness rating after SOX: materiality, reporting on internal control, audit risk / audit failure, business risk, and audit procedures. Similarly, there were several audit topics that get lower effectiveness ratings after SOX: compilation information and reports, review services and reports, internal control reportable differences, governmental auditing, and generally accepted government accounting principles. Given that there were so many substantial topics that must be covered in the auditing course, Blouch et al. argues that there should be an auditing 2 course as a continuation of auditing 1 .

Ulrich and Blouch (2018) analyzed the level of importance and effectiveness of the auditing education curriculum. Using 4 quadrants as a strategy mapping, Ulrich and Blouch mapped 63 auditing topics into quadrant 1 to 4 . The implication for the textbook publisher and authors is that they should deepen the discussion on topics in quadrant 2 , and reduce or eliminate topics in quadrant 4 . For educators, priority should be on topics in quadrants 1 and 2, while the intensity of topic discussion in quadrants 3 and 4 can be reduced or eliminated given the limited time of teaching in the auditing course.

Reinstein et al. (2018) conducted a survey of auditing instructors in the US who are AAA auditing section members. The purpose of the survey is to identify learning resources and learning activities used in auditing 2 or advanced auditing. The results of this study are expected to help other auditing educators to design learning in auditing 2 . The survey showed the variation of learning resources and learning activities used in auditing 2. The primary learning resources used in auditing 2 were textbooks and case studies resources such as education journals, Knapp, self-developed cases, and Trueblood. The main learning activities were case studies, lectures, discussions, group projects, and 
student presentations. The results also showed that the application of technology in auditing such as IDEA and ACL was rarely implemented in the auditing classes.

\section{DISCUSSION}

The main idea of the surveys included in this scoping review centered in two things. Firstly, the relevance of auditing education from the aspect of the content and secondly, the relevance of auditing education from the aspect of pedagogy. Content is related to what topic must be taught so that accounting graduates have in-depth knowledge and skills to become professional auditors. While pedagogy is related to how well to teach the content to achieve the intended learning outcomes.

\section{The Relevance of Auditing Education from the Aspect of Content}

Auditing educators tend to use auditing textbooks as a guide for choosing the content of auditing course (Bryan \& Smith,1997). More than the next two decades, Reinstein (2018) showed that auditing textbooks still dominated the selection of content. Textbooks usage is not limited to determine the content. Other than content, texbooks have been used to determine learning objectives as well as assessment (Irafahmi, Nuris, Zahroh, \& Nagari, 2018). Given the importance of the role of a textbook, it is not surprising that all studies in this scoping review determine the types of auditing topics based on the list of topics in popular auditing textbooks, such as books by Arens, Louwers, and Messier. In addition, studies conducted by Ulrich et al. (2009), Blouch et al. (2016) and Ulrich \& Blouch (2018) not only examine what topics are substantial to teach, but also analyze the level of effectiveness of textbooks in developing auditing topics.

In order to remain relevant to the current audit practices, auditing content must be continually reviewed following the efforts made by the 12 studies included in this scoping review. Albrect \& Sack (2000, cited in Ulrich et al., 2009, p. 64) strongly stated, "we don't need to cover all the traditional material ... throw away what is needed and try to make the program as value added as possible ". This opinion is fully supported by the results of the 12 studies above. Auditing educators do not need to teach all the topics in the auditing textbook. There are topics that are considered substantial, and there are topics that are less substantial so that priority level should be given only to those substantial topics (Bryan \& Smith, 1997; Reinstein et al., 2018). Even if only the topics that are considered substantial are taught, the numbers of topics are still relatively too large to be covered in one auditing course. Some educators proposed an idea of having the new course such as Auditing 2 or Advanced Auditing as the continuation of Auditing 1 (Blouch et al., 2016; Bryan \& Smith, 1997; Johnson et al., 2003; Reinstein et al., 2018).

De Lange, Jackling, and Gut (2006), Hossain, Kummer, and O'Leary (2015) and Willis (2016) stated that the accounting and auditing education curriculum is too crowded. Exposure to high volume of content will reduce students' understanding on more professional oriented content such as auditing technology, thinking skills and communication skills. Biggs and Tang (2011) reminded that "the greatest enemy of understanding is coverage ... If you are determined to cover a lot of things ... they (students) have not had enough time to go into things in depth,... and be able to perform that understanding in different situations "(Gardner, 1993, p. 24 cited in Biggs \& Tang, 2011, p. 43).

Regarding the content or topic selection, it is necessary to compare the perceptions of auditing educators to those of the practitioners', as has been done by McCartney et al. (2002), Greenstein \& McKee (2004), and Armitage \& Poyzer (2010). Academics and practitioners have different views about the priority of auditing content (Armitage, 2008; Armitage \& Poyzer, 2010; Blouch et al., 2015; Bryan \& Smith, 1997; Greenstein \& McKee, 2004; McCartney et al., 2002). For practitioners, auditing technology topics are very important, but auditing educators think differently (Armitage, 2008; Armitage \& Poyzer, 2010; Bryan \& Smith, 1997; Chaffey et al., 2011; Greenstein \& McKee, 2004; McCartney et al., 2002). Considering that the current auditing practices have changed dramatically due to the intensive use of technology (Bierstaker et al., 2001; Herron \& Morozzo, 2008), it is likely for practitioners to expect students to be equipped with technological skills. Unfortunately, Johnson et al. (2003) and Reinstein et al. (2018) proved that up to now the integration of technology in the auditing course is still very limited. The 
results of Greenstein and McKee (2004) showed interesting findings that auditing educators are senior accounting lecturers who tend to have a low level of IT knowledge. Perhaps this is the reason why there is a delay to integrate auditing technology in an auditing course. Another reason is due to auditing educators' expectations to include technology in different courses, such as in Accounting information system course (Armitage, 2008; McCartney et al., 2002). It is interesting to study in the future whether integrating technology in an auditing course or separating auditing technology in different course has different effect on students' learning outcomes.

Besides the topic of auditing technology, a substantial difference between academics and practitioners is about emphasizing practice versus theory. Unlike practitioners who prefer topics related to practice, academics prefer topics related to theory (Armitage \& Poyzer, 2010; Blouch et al., 2015). Because the priority of academics is on teaching theory, the chosen auditing topic is less able to give an accurate picture to students about real auditing practices (Bryan \& Smith, 1997; Chaffey et al., 2011). In their survey of CPAs, Blouch et al., (2015) described "CPA practitioners rank the topics that focus on the practice of auditing higher on importance, including detailed tests of balances, analytical procedures, auditing and business risks, evidence and documentation of work performed, than those that focus more on concepts such as opinion related topics (p.101). In line with this, Fouché (2013) stated that the focus of auditing teaching is still on transferring knowledge, which ignores the importance of bringing the real world of auditing to students.

Although practitioners consider the practice to be more relevant for the development of the professional abilities of students, the theory remains substantial to understand as a basis for conducting auditing practices. Therefore, for Chaffey et al. (2011) and Armitage and Poyzer (2010), the ideal auditing class is a balanced element of theory and practice. Armitage and Poyzer (2010) explained, "the optimal auditing class is one that can provide students not only with the underlying theory but also with enough skills and techniques to succeed in their first job. That is the most substantial "job of an accounting professor - choosing the appropriate blend of theory and practice to be included in their classes" (Armitage \& Poyzer, 2010, p. 76).

\section{The Relevance of Auditing Education from the Aspect of Pedagogy}

The right content will not be meaningful without the right way to teach it. According to the International Accounting Education Standards Board (2017), accounting graduates must have professional competence, beyond knowledge, which includes technical competence, professional skills, and professional values, ethics and attitudes. To achieve this objective, pedagogy such as direct instruction is not sufficient.

Compared with Frakes' research (1987), Johnson et al. (2003) noted that there was an increase in pedagogical aspects, marked by the variety of methods applied in auditing education, such as case studies, group activities, presentations and writing assignments. The results of McCartney et al. (2002), Chaffey et al. (2011) and Reinstein et al. (2018) also showed that both academics and practitioners consider case studies and practitioner guest lectures as an appropriate method for introducing audit practices to students. The emergence of more creative pedagogy after year 2000 is perhaps also an indication of changes in auditing education that is responsive to SOX regulation.

Case studies, according to Biggs and Tang (2011) have advantage to help students understand theory and practice at the same time, termed as 'just-in-time learning' (p. 161). The just-in-time learning could overcome the problem of time constraints to convey theory and practice. Case studies are also potential to integrate various competencies at the same time. Case studies auditing from Andiola, Lambert, and Lynch (2018) and Peaden and Stephens (2013) are the examples. The two case studies, if applied, can develop student competencies in auditing, technology, communication, thinking skills (judgment and skepticism) and teamwork. Drake (2011) introduced another type of case studies that are claimed not to be artificial and retrospective, named 'living case'. This living case uses a real corporate failure setting taken from the mass media to encourage critical appraisal of audit practices.

Related to guest lectures by practitioner, Sanchez, Agoglia, and Brown (2012) uses a useful approach, namely Interactive Professional Learning Experience (IPLE). The idea of IPLE is to bring 
practitioners into auditing classrooms to give lectures on certain topics so students could get meaningful learning experience. Sanchez et al. (2012) provide a touch of interactivity in the relationship between practitioners and students, by asking practitioners to give professional supervisory to the results of student work. IPLE is proven effective in increasing students' learning outcomes and bringing students closer to practitioners (Sanchez et al., 2012). Close collaboration between practitioners and academics is a way to maintain the relevance of content and pedagogy in auditing education (Sanchez et al., 2012).

\section{CONCLUSION}

The relevance of auditing education can be seen from the content and pedagogy aspects. Based on this scoping review, it is clear that there have been efforts to improve the relevance of auditing education through content and pedagogical changes. However, as stated by Johnson et al. (2003), the changes made were not as fast as practitioners' expectation. The concern needs to emphasize on the content considering there is a gap between auditing educators and practitioners in ranking and prioritizing auditing topics that are substantial in auditing courses. Once the appropriate content selected, the next step is to apply the right pedagogy, as discussed above. This scoping review has mapped the existing literature assessing the relevance of auditing education in meeting the demands of the profession. This scoping review has several limitations. Only 3 electronic databases were used, so there may be literature that cannot be traced as it might be included in electronic databases other than ProQuest, Taylor \& Francis and Science Direct. Moreover, the key search terms were not consulted with librarians to determine the appropriateness of key search terms and Boolean operator, such as those conducted by O'Flaherty and Phillips (2015). Further, there is a possibility that auditing education studies also included in the core broad area such as accounting education, so the next scoping review needs to expand the key search term in accounting education. The research question for this study is limited to "What is known from the existing literature about the relevance of undergraduate auditing education to meet contemporary auditing practice?" Future research can add research questions such as "What is known from the existing literature about the approaches that have been taken to keep the relevance of undergraduate auditing education?". By adding this research question, future research could provide comprehensive understanding of the role of auditing education. The majority of mapped literature is set in the US. The relevance of auditing education in other countries, especially in Asian countries, is unknown. Non-US research related to this matter is expected to emerge to provide an overview of the role of auditing education in educating prospective professional auditors.

\section{REFERENCES}

American Institute of Certified Public Accountants. (2018). The AICPA Pre-Certification Core Competency Framework. Retrieved from http://www.aicpa.org/interestareas/accountingeducation/resources/pages/corecompetency.aspx

Andiola, L. M., Lambert, T. A., \& Lynch, E. J. (2018). Sprandel, Inc.: Electronic workpapers, audit documentation, and closing review notes in the audit of accounts receivable. Issues in Accounting Education, 33(2), 43-55. doi:10.2308/iace-52055

Antcliff, M., Doren, R., Harris, L., \& Hayes, D. C. (2012). A case to provide students practice in basic and advanced functions of IDEA software. AIS Educator Journal, 7(1), 69-73.

Apostolou, B., Dorminey, J. W., Hassell, J. M., \& Hickey, A. (2019). Accounting education literature review (2018). Journal of Accounting Education, 47, 1-27. doi:https://doi.org/10.1016/j.jaccedu.2019.02.001

Apostolou, B., Dorminey, J. W., Hassell, J. M., \& Rebele, J. E. (2015). Accounting education literature review (2013-2014). Journal of Accounting Education, 33(2), 69-127. doi:10.1016/j.jaccedu.2015.04.001 
Apostolou, B., Dorminey, J. W., Hassell, J. M., \& Rebele, J. E. (2016). Accounting education literature review (2015). Journal of Accounting Education, 35, 20-55. doi:http://dx.doi.org/10.1016/j.jaccedu.2016.03.002

Apostolou, B., Dorminey, J. W., Hassell, J. M., \& Rebele, J. E. (2017). Accounting education literature review (2016). Journal of Accounting Education. doi:10.1016/j.jaccedu.2017.03.001

Apostolou, B., Dorminey, J. W., Hassell, J. M., \& Rebele, J. E. (2018). Accounting education literature review (2017). Journal of Accounting Education, 43, 1-23. doi:https://doi.org/10.1016/j.jaccedu.2018.02.001

Apostolou, B., Dorminey, J. W., Hassell, J. M., \& Watson, S. F. (2013). Accounting education literature review (2010-2012). Journal of Accounting Education, 31(2), 107-161. doi:http://doi.org/10.1016/j.jaccedu.2013.03.001

Apostolou, B., Hassell, J. M., Rebele, J. E., \& Watson, S. F. (2010). Accounting education literature review (2006-2009). Journal of Accounting Education, 28(3), 145-197. doi:10.1016/j.jaccedu.2011.08.001

Arens, A., \& Elder, R. (2006). Perspectives on Auditing Education after Sarbanes-Oxley. Issues in Accounting Education, 21(4), 345-362. doi:10.2308/iace.2006.21.4.345

Arksey, H., \& O'Malley, L. (2005). Scoping studies: towards a methodological framework. International Journal of Social Research Methodology, 8(1), 19-32. doi:10.1080/1364557032000119616

Armitage, J. (2008). Changes in the importance of topics in auditing education: 2000-2005. Managerial Auditing Journal, 23(9), 935-959. doi:10.1108/02686900810908463

Armitage, J., \& Poyzer, J. K. (2010). Academicians' and Practitioners' Views on the Importance of the Topical Content in the First Auditing Course. American Journal of Business Education, 3(1), 7182.

Bierstaker, J. L., Burnaby, P., \& Thibodeau, J. (2001). The impact of information technology on the audit process: an assessment of the state of the art and implications for the future. Managerial Auditing Journal, 16(3), 159-164. doi:10.1108/02686900110385489

Biggs, J., \& Tang, C. (2011). Teaching for quality learning at university (4th ed.). England: McGrawHill.

Blouch, W., Ulrich, T., \& Michenzi, A. (2015). A CPA Perspective of a Contemporary Auditing Curriculum: Helping to Keep It Relevant. Journal of Business and Accounting, 8(1), 88-101.

Blouch, W., Ulrich, T., \& Michenzi, A. (2016). Effectiveness of Auditing Curricula Revisited. Journal of Business and Accounting, 9(1), 37-56.

Borkowski, S., Bukics, R., \& Welsh, M. (2007). Technology generation upgrades: Are educators and employers on the same page. Pennsylvania CPA Journal, 78(3), 22-27.

Bryan, B. J., \& Smith, L. M. (1997). Faculty perspectives of auditing topics. Issues in Accounting Education, 12(1), 1-14.

Chaffey, J., Van Peursem, K. A., \& Low, M. (2011). Audit Education for Future Professionals: Perceptions of New Zealand Auditors. Accounting Education, 20(2), 153-185. doi:10.1080/09639284.2011.557492

De Lange, P., Jackling, B., \& Gut, A.-M. (2006). Accounting graduates' perceptions of skills emphasis in undergraduate courses: an investigation from two Victorian universities. Accounting and Finance, 46(3), 365. doi:10.1111/j.1467-629X.2006.00173.x

Drake, J. (2011). Adding Value to Audit Education through 'Living' Cases. Accounting Education, 20(2), 203-222. doi:10.1080/09639284.2011.557518

Fouché, J. P. (2013). A renewed call for change in accounting education practices. International Journal of Educational Sciences, 5(2), 137-150. doi:10.1080/09751122.2013.11890071

Frakes, A. H. (1987). Survey of undergraduate auditing education. Journal of Accounting Education, 5(1), 99-126.

Greenstein, M., \& McKee, T. E. (2004). Assurance practitioners' and educators' self-perceived IT knowledge level: an empirical assessment. International Journal of Accounting Information Systems, 5(2), 213-243. doi:10.1016/j.accinf.2004.04.002 
Herron, T., \& Morozzo, M. (2008). The Value of Faculty Internships in Auditing. Current Issues in Auditing, 2(2), A1-A9. doi:10.2308/ciia.2008.2.2.A1

Hossain, M., Kummer, T., \& O'Leary, C. (2015). Successful implementation of written communication across an accounting degree program. Business Education \& Accreditation, 7(1), 43-56.

International Accounting Education Standards Board. (2017). Handbook of International Education Pronouncements. New York: IFAC.

Irafahmi, D. T., Nuris, D. M. r., Zahroh, F., \& Nagari, P. M. (2018). Critical Thinking in Accounting Textbooks. Journal of Education and Learning, 12(1), 21-29.

Johnson, E., Baird, J., Caster, P., \& Dilla, W. (2003). Challenges to audit education for the 21st century: A survey of curricula, course content, and delivery methods. Issues in Accounting Education, 18(3), 241-263. doi:10.2308/iace.2003.18.3.241

Johnston, R., Crooks, V. A., Snyder, J., \& Kingsbury, P. (2010). What is known about the effects of medical tourism in destination and departure countries? A scoping review. International Journal for Equity in Health, 9(1), 24.

McCartney, M. W., Marden, R. E., \& Adair, L. P. (2002). Topical coverage in internal auditing: academic versus practitioner perceptions. Accounting Education, 11(4), 311-329. doi:10.1080/09639280210146342

Munn, Z., Peters, M. D., Stern, C., Tufanaru, C., McArthur, A., \& Aromataris, E. (2018). Systematic review or scoping review? Guidance for authors when choosing between a systematic or scoping review approach. BMC Medical Research Methodology, 18(1), 143.

O'Flaherty, J., \& Phillips, C. (2015). The use of flipped classrooms in higher education: A scoping review. The Internet and Higher Education, 25, 85-95.

O’Brien, K. K., Colquhoun, H., Levac, D., Baxter, L., Tricco, A. C., Straus, S., . . O’Malley, L. (2016). Advancing scoping study methodology: a web-based survey and consultation of perceptions on terminology, definition and methodological steps. BMC health services research, 16(1), 305.

Peaden, D., \& Stephens, N. M. (2013). Old Main Manufacturing: The Case of Unrecorded Sales Discounts. Issues in Accounting Education, 28(1), 173-179. doi:10.2308/iace-50300

Reinstein, A., Churyk, N. T., \& Tate, S. L. (2018). Analyzing pedagogical approaches used in second auditing courses. Advances in Accounting, 42, 110-124. doi:https://doi.org/10.1016/j.adiac.2018.05.001

Sanchez, M. H., Agoglia, C. P., \& Brown, K. F. (2012). The effectiveness of interactive professional learning experiences as a pedagogical tool: Evidence from an audit setting. Journal of Accounting Education, 30(2), 163-172. doi:https://doi.org/10.1016/j.jaccedu.2012.08.004

The Pathways Commission. (2012). Charting a national strategy for the next generation of accountants. Retrieved from http://commons.aaahq.org/files/0b14318188/Pathways_Commission_Final_Report_Complete.pdf

The Pathways Commission. (2015). In pursuit of accounting's curricula of the future. Retrieved from http://commons.aaahq.org/files/3968045e18/Pathways_Report_4_For_Print.pdf

Ulrich, T., \& Blouch, W. (2018). CPA Practitioners' Feedback on A- $\bar{u}$ diting Curriculum. Journal of Business and Accounting, 11(1), 68-81.

Ulrich, T., Michenzi, A., \& Blouch, W. (2009). An Importance-Effectiveness Analysis of The Contemporary Auditing Course. Academy of Educational Leadership Journal, 13(4), 1-17.

Willis, V. F. (2016). A model for teaching technology: Using Excel in an accounting information systems $\begin{array}{lllll}\text { course. Journal of Accounting } & \text { Education, } & 36, & \text { 89. }\end{array}$ doi:https://doi.org/10.1016/j.jaccedu.2016.05.002 